\title{
EFFECT OF TYPE OF FIBER ON THE MECHANICAL PROPERTIES OF HIGH STRENGTH CONCRETE (HSC)
}

\author{
Mohamed, R. A. S. \\ Associate Professor, Civil Engineering Dept., Faculty of Engineering, \\ El-Minia, Egypt.
}

(Received April 16, 2011 Accepted May 2, 2011)

\begin{abstract}
High strength concrete (HSC) has been widely applied worldwide, in recent years, due to its favorable strength and dense microstructures. HSC shows some characteristic and engineering properties different from those of normal strength concrete even they utilize similar raw materials. Great use of the HSC is found in application where durability is important as high way bridge decks, parking structures, industrial, facilities and off-shore structures special structure such as high rise building and bridges with very long span would not have been possible without the development of HSC. However, the applications of HSC are still hindered by its relative brittleness or lack of ductility such a drawback can be overcome by the addition of discontinuous fibers.

The present work investigates the effect of addition of two types of fibers with different ratios; pure polypropylene and steel fibers to high strength concrete in order to diminish some poor performances particularly in case of tensile strength. The effect of the addition of the two types of fibers on the mechanical properties of HSC is studied. The polypropylene fibers and the steel fibers were added at concentration of 0.0, 0.25, 0.5 and $1.0 \%$ by volume. Compression and bending tests were carried out to determine the mechanical properties such as maximum compressive strength, modulus of elasticity, splitting strength and modulus of rupture. On the basis of the experimental results, it can be concluded that, addition of fibers either steel or polypropylene to HSC mixes slightly increases the modulus of rapture $0.5 \%$ of polypropylene improves the modulus of rapture by $10 \%$ while the same value of steel fibers increases it by $15 \%$. Meanwhile, the polypropylene fibers have no influence in the value of the calculated modulus of elasticity. However, steel fibers increases the modulus of elasticity by about $28 \%$.
\end{abstract}

KEYWORDS: HSC, compressive strength, polypropylene and steel fibers, modulus of elasticity.

\section{INTRODUCTION}

The concrete commonly used in engineering structures is a material having high compressive strength but low tensile strength. The tensile strength of concrete whose compressive strength in the level of about $200 \mathrm{MPa}$ is between 1/8 and 1/20 of this value. So, that tensile strength of concrete is generally assumed to be zero in reinforced concrete design. Therefore, many experimental and theoretical studies have been carried out to determine the tensile strength of concrete [1-6]. 
With the concrete technology development, high strength concrete can be readily produced using ordinary cement and aggregate as well as very powerful waterreducing admixtures. The definition of HSC varies geographically and with time. ACI committee 363-1992 [7], concrete having 28 days compressive strength higher than 41 $\mathrm{MPa}$ can be considered as high strength concrete.

The use of fibers in concrete has gained enormous popularity in the last decade. Studies have shown increasing evidence the brittle behavior of HSC can be overcome by the addition of short steel fibers of small diameter in the concrete mix. The addition of steel fibers in a concrete matrix improves all mechanical properties of concrete, especially tensile strength. An understanding of the tensile strength properties of steel fibers reinforced concrete and its variation with fiber amount is an important aspect of successful design. Flexural strength rather than compressive strength is generally specified for pavements, as reported in ACI Committee 544-1982. The combined use of superplasticizer, and supplementary cementing materials (SCM) such as silica fume having a pozzolanic reaction and filler effect which will in turn improve the interface of the materials, thereby enhancing the strength of concrete, can lead to economical high strength concrete with enhanced durability [8-11]. The concrete reinforcing fibers include metal, polymer, and various others. Among the polymer fibers, and polypropylene fibers achieve popularity in the domain of concrete. The polypropylene fibers claimed contribution to the concrete performance subjected to crack opening and slippage. Furthermore, the fibers reinforced the performance under not only compression, flexure and tension, but also under plastic shrinkage cracking [12-14].

The main objective of this research work is directed towards developing a better understanding on the contribution of the content of steel and polypropylene fibers in HSC mixes to characterize their effects on the mechanical properties of it.

\section{EXPERIMENTAL WORK}

The experiments include the measurements of the compressive strength for seven sets of concrete cubes $10 \times 10 \times 10 \mathrm{~cm},(21$ cubes in total $)$ after 28 days from the casting date as well as modulus of elasticity of the concrete prisms $10 \times 10 \times 40 \mathrm{~cm},(21$ prisms in total), modulus of rapture of the concrete prisms $10 \times 10 \times 50 \mathrm{~cm}$ and also the splitting strength of concrete cylinders $15 \times 30 \mathrm{~cm}$, (21 cylinders in total $)$ all made of the same seven sets of concrete mixes. In all these test specimens however, the same amount of cement, sand and dolomite were used in all test specimens. A water cement ratio of 0.3 was used. Test specimens free from fibers (control mix) were prepared as a base of comparison. The used white colour pure polypropylene fibers have 0.91 gram $/ \mathrm{cm} 3$ density, $370 \mathrm{~N} / \mathrm{mm}^{2}$ tensile strength and $3750 \mathrm{~N} / \mathrm{mm}^{2}$ modulus of elasticity with different ratios $(0.25,0.5$ and $1.0 \%$ by volume of concrete). Steel fiber with a rectangular cross-section and length of 32 having a commercial name (Harix) was used with the same ratios of polypropylene fibers. Details of all concrete mixes are given in Table (1). To fabricate the previous concrete mixes, a natural sand, natural dolomite supplied from Suez quarries with $10 \%$ silica fume by weight of cement as well as a constant amount of super-plasticizer (Addicrete BVF) equals $1.5 \mathrm{litre} / \mathrm{m}^{3}$ were used. Details of physical and mechanical properties of the used sand and dolomite are given 
in Table (2). An ordinary portland cement was used in this investigation and the mechanical properties of it are given in Table (3).

Table (1). Details of concrete mixes

\begin{tabular}{|c|c|c|c|c|c|c|c|c|}
\hline $\begin{array}{c}\text { Group } \\
\text { No. }\end{array}$ & $\begin{array}{l}\text { Mix } \\
\text { No. }\end{array}$ & $\begin{array}{c}\text { Cement } \\
\text { Content } \\
\mathrm{Kg} / \mathrm{m}^{3}\end{array}$ & $\begin{array}{c}\text { Silica } \\
\text { fume } \\
\text { content }\end{array}$ & $\begin{array}{l}\text { Sand } \\
\mathrm{Kg} / \mathrm{m}^{3}\end{array}$ & $\begin{array}{c}\text { Dolomite } \\
\mathrm{Kg} / \mathrm{m}^{3}\end{array}$ & $\begin{array}{c}\text { Fiber } \\
\text { content } \\
\text { By } \\
\text { volume of } \\
\text { concrete }\end{array}$ & $\begin{array}{l}\text { Type of } \\
\text { fibers }\end{array}$ & $\begin{array}{c}\text { Water } \\
\text { content } \\
\text { Litre } / \mathbf{m}^{3}\end{array}$ \\
\hline I & 1 & \multirow{7}{*}{450.0} & \multirow{7}{*}{$\begin{array}{c}10 \% \text { by } \\
\text { weight } \\
\text { of } \\
\text { cement }\end{array}$} & 760 & 1140 & 0.0 & No & 144 \\
\hline \multirow{3}{*}{ II } & 2 & & & \multirow{3}{*}{760} & \multirow{3}{*}{1140} & $0.25 \%$ & \multirow{3}{*}{ Steel } & \multirow{3}{*}{144} \\
\hline & 3 & & & & & $0.50 \%$ & & \\
\hline & 4 & & & & & $1.00 \%$ & & \\
\hline \multirow{3}{*}{ III } & 5 & & & \multirow{3}{*}{760} & \multirow{3}{*}{1140} & $0.25 \%$ & \multirow{3}{*}{$\begin{array}{c}\text { Polypro } \\
\text { pylene }\end{array}$} & \multirow{3}{*}{144} \\
\hline & 6 & & & & & $0.50 \%$ & & \\
\hline & 7 & & & & & $1.00 \%$ & & \\
\hline
\end{tabular}

Table (2). Physical properties of the used sand and Dolomite

\begin{tabular}{|c|c|c|}
\hline Property & $\begin{array}{c}\text { Test results of } \\
\text { sand }\end{array}$ & $\begin{array}{c}\text { Test results of } \\
\text { dolomite }\end{array}$ \\
\hline Specific weight $\left(\mathrm{t} / \mathrm{m}^{3}\right)$ & 2.65 & 2.73 \\
\hline Volume weight $\left(\mathrm{t} / \mathrm{m}^{3}\right)$ & 1.65 & 1.71 \\
\hline Absorption $(24 \mathrm{hrs})$ & $0.65 \%$ by weight & $0.42 \%$ by weight \\
\hline$\%$ of fine materials & $1.0 \%$ by weight & Not determined \\
\hline Crushing value & - & $16 \%$ \\
\hline Voids ratio & $37.7 \%$ & $37.36 \%$ \\
\hline
\end{tabular}

Table (3) Properties of the used ordinary portland cement (O. P. C).

\begin{tabular}{|c|c|c|}
\hline Mechanical properties & $\begin{array}{c}\text { Test } \\
\text { results }\end{array}$ & E.S.S limits \\
\hline Specific gravity & 3.15 & 3.15 \\
\hline Fineness \% & $6.2 \%$ & Max 10\% \\
\hline Specific surface $\mathrm{cm}^{2} / \mathrm{gr}$. & 4119 & Min 2800 \\
\hline Water demand \% & 27 & Min $25, \max 30$ \\
\hline Initial setting time (minute) & 100 & Min $45 \mathrm{~min}$. \\
\hline Final setting time (minute) & 160 & Max $10 \mathrm{hr}$. \\
\hline Soundness (mm) & $1.0 \mathrm{~mm}$ & Max $10 \mathrm{~mm}$. \\
\hline Compressive strength & 280 & Min $183 \mathrm{Kg} / \mathrm{cm}^{2}$ \\
At 3 days $\mathrm{Kg} / \mathrm{cm}^{2}$ & 300 & Min $275 \mathrm{Kg} / \mathrm{cm}^{2}$ \\
\hline At 7 days $\mathrm{Kg} / \mathrm{cm}^{2}$ &
\end{tabular}

Tap water was used in all concrete mixes. Mixing of concrete components was completed by using a horizontal rotating counter flow mixer pan. Prior rotating the mixer pan, the pan mixer was wetted and amounts of the sand, dolomite were added 
together into the mixer then, cement and silica fume were also added to the mixer. Finally the mixing water and the Adicrete P.V.F (with a constant content $=1.5$ litre/m3) and all constituents were mixed to produce the concrete. In case of using fibers, the fibers were spread randomly during mixing. The concrete was charged out from the mixer bowl and then placed in moulds and compacted according to the standard procedures.

The mixing operation was carried out in accordance to the Egyptian Standard Specifications (ESS). Before casting directly, the internal surfaces of the moulds were coated with a thin layer of mineral oil. Fresh concrete was taken from the mixer and poured into the moulds. Mechanical vibration was applied to all concrete moulds. After that, the top surfaces of the specimens were finished and leveled then; the specimens were kept in the laboratory. A standard curing regime was started and continued until the date of testing.

The experiments of all test specimens contained the measurements of the compressive strength of the seven sets of concrete mixes throughout testing the cubes. Modulus of rapture of concrete prisms and splitting strength of concrete cylinders were determined. The modulus of elasticity obtained from concrete prisms was calculated.

\section{TEST RESULTS AND DISCUSSION}

The cubic compressive strength, the cylindrical compressive strength, Modulus of rapture, splitting strength and modulus of elasticity results of concrete having different ratios of polypropylene fibers and steel fibers (by volume of concrete) after 28 days are recorded in tables (4).

Table(4) Mechanical properties of HSC with different contents and types of fibers.

\begin{tabular}{|c|c|c|c|c|c|c|}
\hline $\begin{array}{c}\text { Type of } \\
\text { fiber }\end{array}$ & $\begin{array}{c}\text { fiber } \\
\text { content } \\
(\mathbf{\%})\end{array}$ & $\begin{array}{c}\text { Cubic } \\
\text { compressive } \\
\text { strength } \\
\mathbf{K g} / \mathbf{c m}^{2}\end{array}$ & $\begin{array}{c}\text { Cylindrical } \\
\text { compressive } \\
\text { strength } \\
\mathbf{K g} / \mathbf{c m}^{2}\end{array}$ & $\begin{array}{c}\text { Modulus } \\
\text { of rapture } \\
\mathbf{K g} / \mathbf{c m}^{2}\end{array}$ & $\begin{array}{c}\text { Splitting } \\
\text { strength } \\
\mathbf{K g} / \mathbf{c m}^{2}\end{array}$ & $\begin{array}{c}\text { Modulus of } \\
\text { elasticity } \\
\mathbf{K g} / \mathbf{c m}^{2}\end{array}$ \\
\hline \multirow{2}{*}{$\begin{array}{c}\text { Polypro } \\
\text {-pylene } \\
\text { fibers }\end{array}$} & 0.0 & 720 & 510 & 55 & 42.8 & $5.12 \times 10^{5}$ \\
\cline { 2 - 7 } & 0.25 & 740 & 532 & 59.5 & 43.3 & $5.12 \times 10^{5}$ \\
\cline { 2 - 7 } & 0.5 & 767 & 542 & 61.9 & 44.9 & $5.12 \times 10^{5}$ \\
\hline \multirow{3}{*}{$\begin{array}{c}\text { Steel } \\
\text { fibers }\end{array}$} & 1.0 & 733 & 526 & 58.0 & 45.2 & $5.04 \times 10^{5}$ \\
\cline { 2 - 7 } & 0.0 & 720 & 510 & 55 & 42.8 & $5.12 \times 10^{5}$ \\
\cline { 2 - 7 } & 0.5 & 740 & 535 & 58 & 47.7 & $6.53 \times 10^{5}$ \\
\cline { 2 - 7 } & 1.0 & 796 & 574 & 65.4 & 53.0 & $7.00 \times 10^{5}$ \\
\hline
\end{tabular}

The addition of polypropylene fibers caused a reduction in the cubic compressive strength and the cylindrical compressive strength as the percentage of polypropylene fibers increased more than $(0.5 \%)$ by volume of concrete as shown in figures (1\&2). 


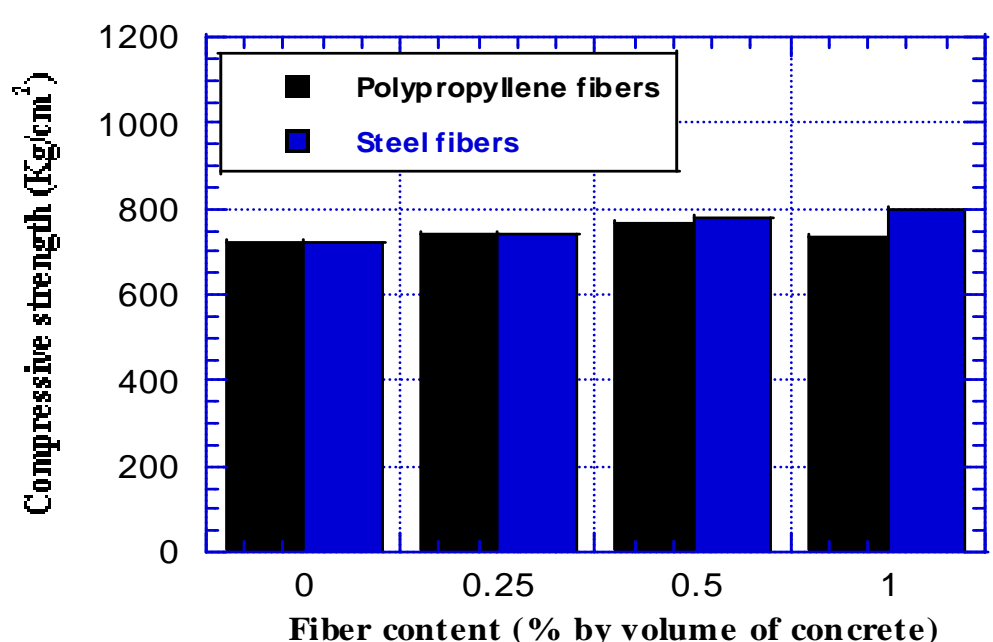

Fig. (1) Relationship between the compressive strength of concrete cubes with fiber content ( $\%$ by volume of concrete) after 28 days of age.

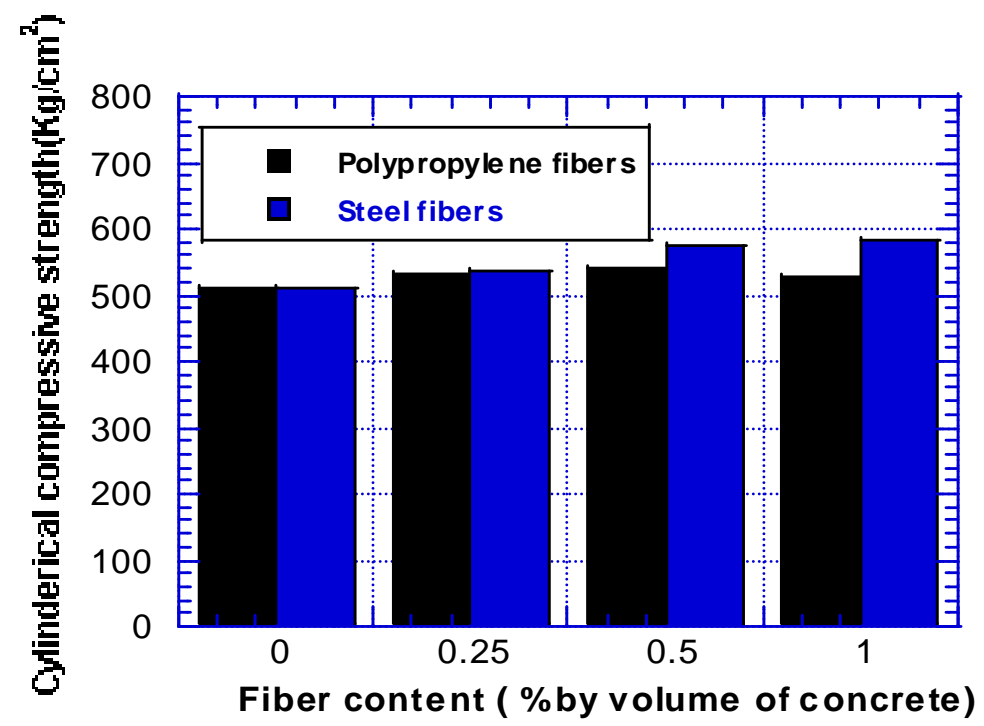

Fig. (2) Relationship between the compressive strength of concrete cylinders with fiber content (\% by volume of concrete) after 28 days of age.

This reduction of strength may be due to the low modulus of elasticity of the polypropylene fiber, thus causing (de-bonding) between the fiber and matrix and the propagation of micro cracks because of the poor physicochemical bonding strength with cement paste. Therefore, the failure occurred with lower load when compared with the control mix. From figure (1\&2), it can be also observed that, the addition of steel fibers produced an increase in the compressive strength of concrete either from testing cubes or cylinders with all volume of fibers used in the research. 
The splitting strength results obtained from testing the cylindrical concrete specimens made of polypropylene and steel fibers with different contents of fibers are illustrated in figure (3). Table 4 and Figure 3 show that the peak value of the splitting tensile strength depends on the fiber content, type of fiber and the compressive strength. Increasing the steel fiber content from 0.0 to $1.0 \%$ increases the splitting tensile strength by about $41.12 \%$. Meanwhile the increasing of polypropylene fiber content from 0.0 to 1.0 increases the splitting tensile strength by about $5.61 \%$.

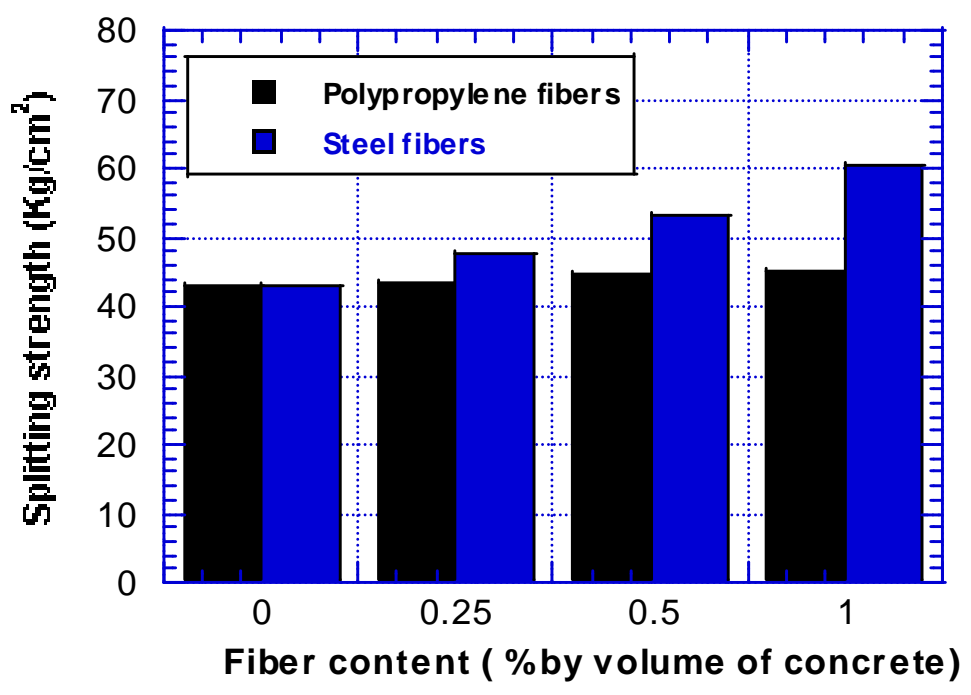

Fig. (3) Relationship between the splitting strength of concrete prisms with fiber content ( $\%$ by volume of concrete) after 28 days of age.

The flexural strength (modulus of rupture) tests were performed using $10 \times 10$ $\times 50 \mathrm{~cm}$ prisms loaded at third points. Table (4) and Fig.(4) show that, an improvement in the values of modulus of rupture were gained as a results of adding fibers in concrete mixes. For example increasing of steel fiber volume from 0.0 to $1.0 \%$, causes an increase in the modulus of rupture by about $22.36 \%$. Meanwhile increasing polypropylene fiber volume content from 0.0 to 1.0 causes an increase in splitting tensile strength by about $5.45 \%$.

Results of beam specimens showed that, concrete beams without fiber produced the lowest ductility, and once the maximum tensile stress was reached the beam failed suddenly after the occurrence of the first crack without warning. The failure characteristics were, however, completely changed as a result of the addition of fibers. After the occurrence of initial cracking, the specimen did not fail and the randomly oriented fibers crossing the cracked section resisted the propagation of cracks and separation of the section. 


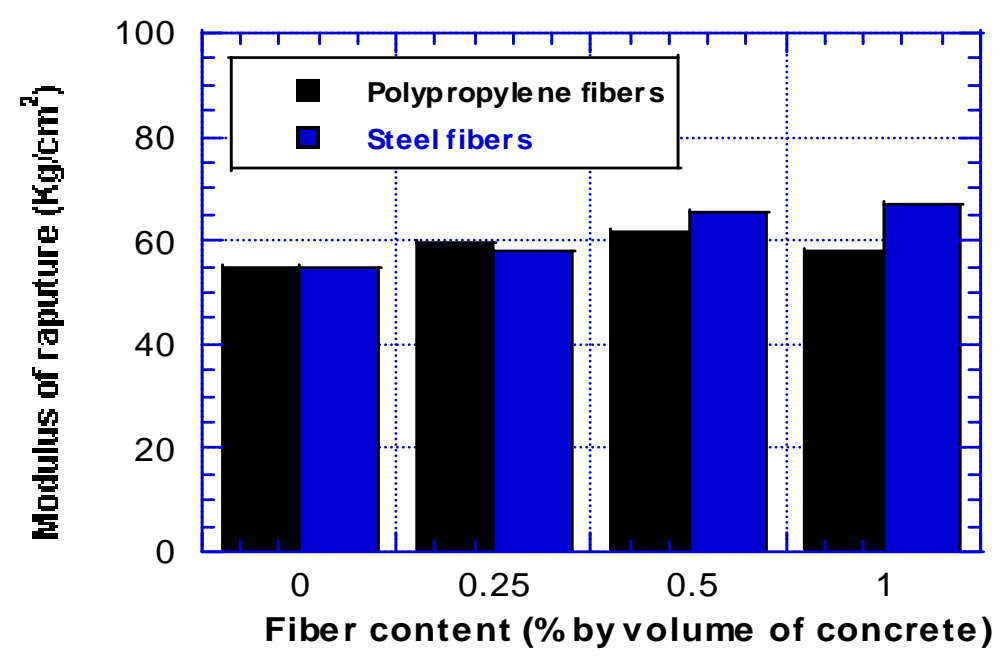

Fig. (4) Relationship between the modulus of rapture of concrete prisms with fiber content ( $\%$ by volume of concrete) after 28 days of age.

The initial modulus of elasticity for all concrete specimens made of polypropylene and steel fibers with different volume contents of fibers are illustrated in Figure (5).

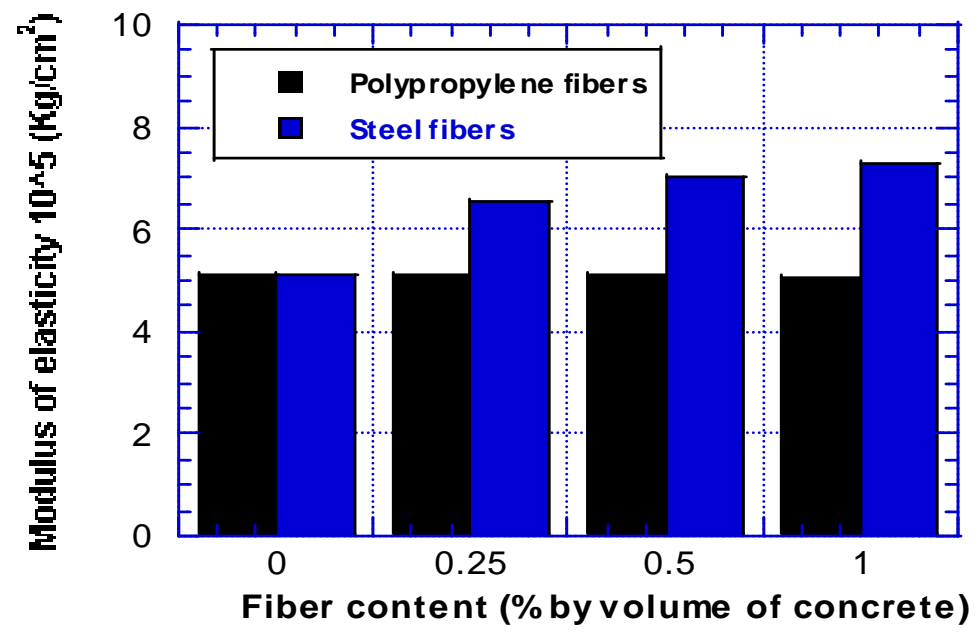

Fig. (5) Relationship between the modulus of elasticity of concrete prisms with fiber content ( $\%$ by volume of concrete) after 28 days of age.

Figure 5 shows that the value of the initial modulus of elasticity for all tested specimens depends on the fiber volume content and type of fiber. Increasing the steel fiber volume content from 0.0 to $1.0 \%$ increases the initial modulus of elasticity by about $42.19 \%$. Meanwhile increasing of polypropylene fiber volume content from 0.0 to 1.0 causes no significant effect the values of the initial modulus of elasticity. 


\section{CONCLUSIONS}

Based on the present investigation, the following conclusions, with respect to the effect of the type of fibers and its content on the mechanical properties of HSC, are drawn:

1. Polypropylene fibers have no influence in the value of the calculated modulus of elasticity.

2. Steel fibers increased the modulus of elasticity by about $28 \%$.

3. Addition of fibers either steel or polypropylene to HSC mixes slightly increases the modulus of rapture, $0.5 \%$ of polypropylene improved the modulus of rupture by $10 \%$ while 0.5 of steel fibers increased it by $15 \%$.

4. The ratio between cylinder and cube compressive strength for all fibrous concrete mixes is 0.73 , following the same behavior of normal and high strength concrete.

\section{REFERENCES}

1. Rossignolo J A, Agnesini M V C, Moaris J A, "Properties of high performance LWAC for precast structures with Brazilian light weight aggregates", Cement and Concrete Composite, Vol. 25, No. 1, pp. 77-82, 2003.

2. Aitcin P C, Mehta P K, ACI Material Journal, 2-87 (1990)103.

3. Iravani S. ACI Material Journal, 5-93 (1996) 416.

4. Marzouk H, Chen Z W, ASCE Journal Material Civil Eng. 72 (1995) 108.

5. Xie N X, Liu W Y, ACI Material Journal, 863 (1989)214.

6. Yan D, Lin G, "Dynamic properties of concretein direct tension", Cement and Concrete Research, Vol. 36, No. 7, pp. 1371-1378, 2006.

7. ACI Committee 363, "State Of the Art Report On High Strength Concrete", ACI 363R-92, American Concrete Institute, 1992.

8. L.S. Hsu and C.T.T. Hsu, "Stress-Strain Behavior Of Steel Fiber Reinforced High Strength Concrete Under Compression", ACI Materials Journal, 91(4)(1994), pp. 448-457.

9. S. Bhanja and B. Sengupta, "Influence of Silica Fume on the Tensile Strength of Concrete", Cement and Concrete Research, Vol. 35, No. 4, pp 743-747, 2005.

10. F.F. Wafa and S. A. Ashour, "Mechanical Properties of High Strength Fiber Reniforced Concrete", ACI Materials Journal , 89(5)(1992), pp. 445-455.

11. B. H. Bharatkumar, R. Narayanan, B. K. Raghuprasad, and D. S. Ramamoortht, "Mix proportioning of high performance concrete", Cement and Concrete Composites, Vol. 23, No. 1, pp.71-80, 2001

12. Perez-Pena M., Mobasher B., "Mechanical properties of fiber reinforced lightweight concrete composites", Cement Concrete Research, Vol. 24, No. 6, pp. 1121-1132, 1994.

13. Kutz S., Balaguru P., "Post crack creep of polymeric fiber-reinforced concrete in flexure", Cement and Concrete Research, Vol. 30, No. 2, pp. 183-190, 2000.

14. Bayasi z., Melntyre M., "Application of fibrilled polypropylene fibers for restraint of plastic shrinkage cracking in silica fume concrete", ACI Material Journal, Vol. 99, No. 4, pp.337-344, 2002. 


\section{تأثير نوع الألياف على الخواص الميكانيكية للخرسانة العالية المقاومة}

شهدت الخرسانة منذ بدء اكتشافها عمليات تطوبر متتالية تزامناً مع التطور الذي شهدته شتى مناحي الحياة المعاصرة، والذي بدوره أدى إلى اكتشاف مواد جديدة ينت إضافتها إلى الخلطة الخرسانية لتعمل على تحسين خواصها ورفع كفاعتها. تعتبر المقاومة من أهم خواص الخرسانة حيث تعطي مؤشراً واضحاً لمعظم خواص الخرسانة الأخرى ففي حال توفر مقاومة عالية للخرسانة فهذا يعني أن بنية الخرسانة مترابطة ومتراصة والترابط بين الركام والعجينة الإسمنتية جيد ولا يوجد منطقة بينية عازلة تضعف الترابط بين الركام والعجينة الإسمنتية وهذا يؤدي إلى ارتفاع مقاومة الثد بند ومعاير المرونة وتقليل نسبة الامتصاص والنفاذية بسبب التراص الجيد وقلة الشقوق والفراغات وتعتبر الخرسانة العالية المقاومة ذات أهنمام كبير لاى كثثر من الباحثين فى هذه الأيام وذلك لإنتشار إستخدامها فى مجالات

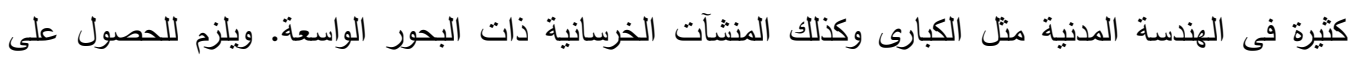
خرسانة عالية المقاومة الاهتمام بنوعية ونسب جميع مكوناتها، وتلعب نسبة الماء إلى الاسمنت (w/c) دوراً كبيراً في التأثير على مقاومة الخرسانة، فمن المعروف أن زيادة نسبة الماء إلى الإسمنت للوفاء بمنطلبات التشغيل تتخفض تبعاً لذلك مقاومة الخرسانة بشكل كبير ولذا يلزم تقليل نسبة الماء إلى الإسمنت مع المحافظة على درجة التتغيل المطلوبة، ويتم ذلك عن طريق إضافة بعض الملدنات المتفوقة مثل (Superplasticizers) ونظرا لضعف المقاومة فى الثد فأنه يلزم تحسين مقاومة الخرسانة من هذا الجانب. يتضمن هذا البحث دراسة تأثنر استخدام نوعين من الألياف (ألياف الصلب وألياف البولي بوربلين) بنسب مختلفة وهى صفر ، 0.25 \% ، 0.50 \% ، 1.0 \% من حجم الخرسانة لكل نوع على حده ونم عمل مكعبات

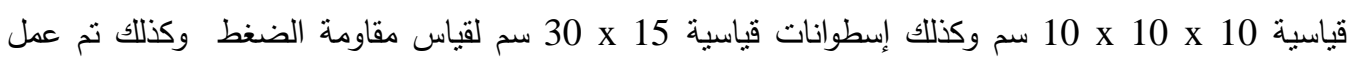
50 x10 x 10 أسطوانات قياسية بأبعاد 15 x سم لقياس مقاومة الأنفلاق وتم عمل منشورات قياسية بأبعاد سم لقياس معاير الكسر تحت تأثير عزم الإنحناء وتم عمل منشورات قياسية بأبعاد 10 x 10 x 10 سم لقياس باس معاير المرونة للخرسانة وتم تتفيذ جميع الأختبارات على العينات المذكورة بعاليه بعد عمر 28 يوم من تاريخ الصب ونم أخذ منوسط النتائج لثلاث عينات لكل إختبار على حدة. أظهرت النتائج أن إستخدام نسبة من الألياف المصنوعة من الصلب مقدارها 0.5 \% من حجم الخرسانة نؤدى إلى زبادة قيمة معاير الكسر بمقدار 15 \% بينما إضافة نفس النسبة من ألياف البولى بروبلين تؤدى إلى زبيادة

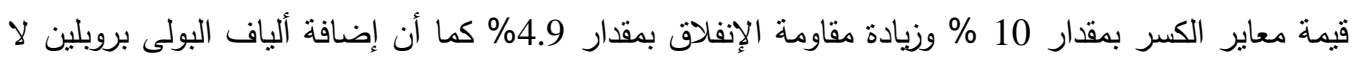
تؤثز على قيمة معاير المرونة للخرسانة عند جميع النسب المضافة بينما عند إضافة ألباف الصلب نسبة 1 \% فإن معاير المرونة يزيد بمقدار 28 \% ومقاومة الإنفلاق تزيد بمقدار 41.1 \% 